\title{
Survival after Transfer of Bovine Embryos Frozen using the Seeding Method by Immobilized Silver lodide
}

\author{
Toshiyuki KoJıma, Kunio Onodera*, Tadashi Soma \\ and Norihiko OgurI \\ Department of Animal Reproduction, National Institute of Animal Industry, \\ Tsukuba-Norindanchi, P. O. Box 5, Ibaraki, 305, JAPAN \\ *Aomori Animal Husbandry Experimental Station
}

(Accepted for publication June 13, 1988)

\begin{abstract}
Summary. The present study was undertaken to assess in vivo survival of bovine embryos frozen using the ice-seeding method with the immobilized silver iodide. Silver iodide was added into $2 \%$ sodium alginate solution in distilled water to obtain a final concentration of $2 \% \mathrm{w} / \mathrm{v}$. The sol resulting from the above mixture was let fall drop by drop into $100 \mathrm{mM}$ calcium chloride (dihydrate) solution in distilled water. Day-7 excellent or good five embryos were loaded individually into 0.25 ml-plastic straw with $200 \mu \mathrm{l}$ of $10 \%$ (v/v) glycerol in PB1 supplemented with $10 \%$ FBS and one droplet of the immobilized silver iodide. The loaded plastic straws were refrigerated until $-36^{\circ} \mathrm{C}$ at the gradual cooling rate of $0.3^{\circ} \mathrm{C} / \mathrm{min}$ after 5 min-holding at $-7^{\circ} \mathrm{C}$, and were followed by plunging into liquid nitrogen. After rapid thawing and sucrose-dilution, one embryo was discarded due to detection of sign of degeneration. Four embryos were transferred to two synchronized recipient-cows by nonsurgical method. The both recipients became pregnant. The result of the present study suggested that the ice-seeding method by the immobilized silver iodide did not disturb in vivo survival of frozen-thawed bovine embryos. KEY WORDS; IMMOBILIZATION, SILVER IODIDE, ICE-SEEDING, CRYOPRESERVATION, BOVINE EMBRYO.
\end{abstract}

Jpn J Anim Reprod 34, 149-152, 1988

\section{固定化ヨウ化銀による植水方法を応用して凍結された 牛胚の移植試験}

\author{
小島 敏之・小野寺邦男*・相馬 正・小栗 紀彦 \\ 農水省畜試, 青森県畜試 $\mathbf{T} 305$ 茨城県筑波農林研究団地内局私書箱 5 号
}

氷晶誘起物質としてのヨウ化銀（Vonnegut, 1947; Mason, 1962）が哺乳動物胚の凍結保存のための凍結媒 液への氷晶形成誘起剤として利用でき, 従来の植水方法 を代替できることは既に報告した（Kojima et al, 1986； Kojima et al, 1987a; Kojima et al, 1987b)。さらに, 上記のヨウ化銀による植水方法を実用化するために，ア ルギン酸で固定化したヨウ化銀が凍結媒液中で氷晶形成 誘起剂として利用でき, 凍結融解された家鬼胚と牛胚の 体外培養系での生存性が優れていることも既に報告した
(Kojima et al, 1988b; Kojima et al, 1988c)。本研究 では，この固定化ヨウ化銀による植水法を用いて凍結し た牛胚を受胚牛へ移植した後の生存性を確認するために 移植試験を実施した。

\section{材料及び方法}

\section{供試した牛胚の由来}

本試験に供した牛胚は，性周期の 7 日目（発情日を 0 日とする）に非外科的に採取し 4 段階評価でA及びB 
ンクの桑実期〜胚盤胞期のもので, $\mathrm{FSH}-\mathrm{P}$ 製剤(アント リン，デンカ製薬）により多排卵処理されたホルスタイ ン種経産牛由来のもの 3 個, 及び自然発情による黒毛和 種未経産牛由来のもの 2 個の計 5 個である。

\section{固定化ヨウ化銀の作製}

ヨウ化銀を $2 \%$ の濃度になるように， $2 \%$ アルギン酸 ナトリウム水溶液（ゾル状）に加え，超音波破砕機によ り細粒化したのちマグネチックスターラーを用いてよく 㩖拌した。そのヨウ化銀アルギン酸ナトリウム混合液を

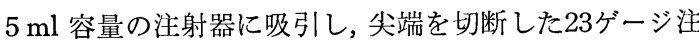
射針を用い $100 \mathrm{mM}$ 塩化カルシウム水溶液中に一滴ずつ 滴下してヨウ化銀を固定化した。ヨウ化銀一アルギン酸 ナトリウム混合液は, 塩化カルシウム溶液中に入るとす ぐに球状のドロップレットとなる。その後, 固定化ヨウ 化銀を塩化カルシウム液中から取り出し蒸留水で $2 \sim 3$ 国洗浄し， $121^{\circ} \mathrm{C} ・ 20$ 分の条件でオートクレープ隇菌を 行った。そして, 使用時まで $4{ }^{\circ} \mathrm{C}$ の蒸留水中に保存し た。

\section{凍結方法}

胚を $10 \%(\mathrm{v} / \mathrm{v})$ グリセロール・PB1 (10\% FBS添加) 溶液（以下，凍結媒液と称する）中へ移し，冷却開始ま で室温 $\left(\right.$ 約 $25^{\circ} \mathrm{C}$ ) で30分間平衡させた。この間に $0.25 \mathrm{ml}$ 容量のプラスチックストロー(I.M.V., フランス) 内へ 1 個の胚を含む凍結媒液 $200 \mu \mathrm{l}$ と共に 1 個の固定化ヨ ウ化銀ドロップレットを納めた後，ストロー端を加熱し て閉封した (Fig. 1)。プログラムフリーザー（ダイサン

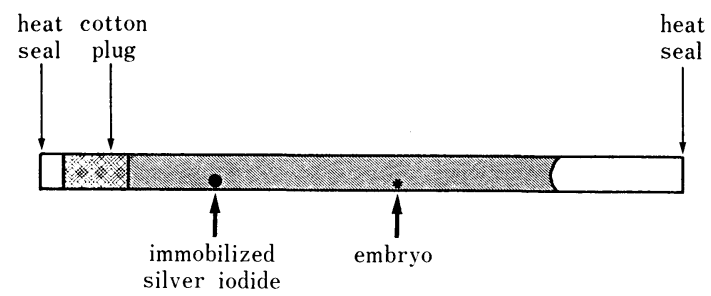

Fig. 1. Diagram of the $0.25 \mathrm{ml}$-capacity plastic straw containing one droplet of immobilized silver iodide and one bovine embryo which were immersed in $10 \%$ ( $\mathrm{v} / \mathrm{v})$ glycerol in PB1 supplemented with $10 \%$ FBS. The straw was collocated at horizontal position in the cooling chamber of the programmable freezer.

FFP-190, 大阪酸素工業) の冷却槽内にストローを水平 に保持し, 室温から $-7^{\circ} \mathrm{C}$ まで $1^{\circ} \mathrm{C} / \mathrm{min}$ で冷却後 5 分 間冷却槽内の温度を $-7^{\circ} \mathrm{C}$ に保った。 $-7^{\circ} \mathrm{C}$ から $-36^{\circ} \mathrm{C}$ まで $0.3^{\circ} \mathrm{C} / \mathrm{min}$ で冷却し続けた後, ストローを液体窒素 中に浸漬し, 融解時まで保存した。冷却途中外部からの
植水操作は行わず，またプログラムフリーザーの自動植 水装置も作動させなかった。

\section{融解及び受胚牛への移植}

移植当日に $37^{\circ} \mathrm{C}$ の温水中にストローを浸漬して融解 した。0.5 M ショ糖・PB1 溶液 $150 \mu 1$ に次いで, 回収 した肧を含む涷結媒液 $20 \mu 1$ を $0.25 \mathrm{ml}$ ストローに気泡 を隔てて再吸引し，両液を混合後綿栓部を下にしてスト ローを鉛直方向に保持して 5 分間静置した。次いで，ス トローから胚を回収し，別に用意した $0.5 \mathrm{M}$ ショ糖・ $\mathrm{PB} 1$ 溶液 $5 \mathrm{ml}$ を入れたディッシュ内に胚を移し，0.5 M ショ糖・PB1 溶液と 5 分間作用させた。PB1 で 2 回洗浄 し形態観察を行った後, 移植のためにプラスチックスト ロ一内に吸引して移植場所へ運搬した。自然発情の性周 期 7 日目のホルスタイン種経産牛に 1 頭あたり 2 個の胚 を黄体側子宮角に頸管経由法により移植した。妊娠の成 否は, 超音波診断装置を用いて好.娠45及び75日目に確認 した。

\section{結果及び考察}

凍結融解技術を評価するには, 体外培養系による凍結 融解胚の生存性を指標とするのが現在のところ最も確実 な方法であると考えられる。受泼動物へ胚を移植する方 法は, 凍結融解技術以外のさまざまな要因が受胎の成立 に関与するゆえに，凍結融解技術に対して正確な評価を 下しにくい。ただし, 体外培養系での胚の発育が生殖道 内での胚の発育及び胎児への成長を完全に保証すること は証明されていないので，移植による受胎を確認してお くことは必要である。本研究の場合, 特にヨウ化銀の胚 に対する有害性の問題が未解決であるので, 移植後の生 存性を確認して打く必要があった。

Table 1 亿各凍結融解胚の移植成績を示した。合計 5 個の肧を融解し 2 頭の受肧牛にそれぞれ 2 個を移植した 結果，いずれの受肧牛も受胎した。残りの 1 個は変性部 分が多かったために移植には供しなかった。なお，受胎 した 2 頭の子宮を超音波診断装置により検査した結果, 双胎を確認することはできなかった。しかし, 移植した 4 個の胚のうち，少なくとも 2 個が胎児に発育したこと が認められた。著者らの家鬼胚と牛胚を用いた実験 (Kojima et al, 1988b) では, 固定化ヨウ化銀による植 氷方法が胈の凍結保存に有効であることを体外培養系に おける発育成績から確認したが，本研究では受胚牛の子 宮内に打ける牛胚の生存を指標としてこの方法の有効性 を再確認できた。

本法は, 氷晶形成機構の内いわゆる heterogeneous 
Table 1. Information of donors and embryos used in the present study and the result of transfer through cervix to appropriately synchronized recipients

\begin{tabular}{|c|c|c|c|c|c|}
\hline \multirow{2}{*}{ Donor No. } & \multicolumn{3}{|c|}{ Embryo } & \multirow{2}{*}{ Recipient No. } & \multirow{2}{*}{ Pregnant } \\
\hline & Stage $^{\mathrm{a}}$ & Quality & Qualityc & & \\
\hline $1106(\mathrm{JB})^{*}$ & EB & $\mathrm{A}$ & $\mathrm{A}$ & $5(\mathrm{H})$ & \multirow{2}{*}{+} \\
\hline $2035(\mathrm{JB})^{*}$ & $\mathbf{M}$ & A & A & $5(\mathrm{H})$ & \\
\hline $282(\mathrm{H})^{* *}$ & B & A & $\mathbf{B}$ & $276(\mathrm{H})$ & \multirow{3}{*}{+} \\
\hline $282(\mathrm{H})^{* *}$ & EB & A & B & $276(\mathrm{H})$ & \\
\hline $282(\mathrm{H})^{* *}$ & EB & B & $\mathrm{D}$ & & \\
\hline
\end{tabular}

* indicates donor non-superovulated.

** indicates donor superovulated.

a ' $M$ ' means morula, 'EB' early blastocyst and ' $B$ ' blastocyst.

b before freezing.

c after thawing.

nucleation あるいは catalytic nucleation の機構(Franks, 1987）を応用したもので, その水晶核に氷晶誘起物質と して現在のところ最も効果が高いといわれているヨウ化 録を用いることによって, 凍結媒液への水晶形成誘起の 確実性を高めることができた。現今の植水方法の殆どが 容器の外側から容器壁を通して冷体を接触させる機構を 応用したものであるが，冷体による刺激の必要十分条件 が未解明であるので，その確実性は種々の実験条件に微 妙に影響されることは否定できないと考えられる。ま た，密閉されたプログラムフリーザーを用いて胈を凍結 する場合は, 植水後の水晶形成を直視下で確認すること は試料の温度上昇の原因となることから，より確実性の 高い植氷方法を採用する必要がある。その意味で, ヨウ 化銀を用いる氷晶形成誘起に関する一連の研究が, 肧の 凍結保存技術のために現在汎用されている緩速冷却法の 行程における植水の重要性を再認識する契機となるかも 知れない。固定化ヨウ化銀は，確実に $-7^{\circ} \mathrm{C}$ 付近でそれ 自体がまず氷晶化するので（Kojima et al. 1988a），全 く自然な条件下で凍結媒液に氷晶形成を誘起することが できる。

ヨウ化銀による植水方法を応用する場合， ヨウ化銀の 胚に及ぼす有害性が最も懸念されるが，現在まで種々の 角度から検討したが確認されていない (Kojima et al. 1986; Kojima et al. 1987a)。また, 家免桑実胚を 1 個 の固定化ヨウ化銀ドロップレットと共に培養液中に入れ 48時間培盖を続けた結果, 家鬼胚の発育に対する有害作 用は認められず，培養した全ての胚が拡張しきった後に 脱款した (Kojima, unpublished data)。

\section{謝辞}

本論文を御校閲して戴いた当場繁殖部長花田章博士及 び同部胎生発育研究室長塩谷康生氏に感謝する。また, 繁殖部生殖機能制御研究室主任研究官富塚常夫氏, 同部 繁殖第 2 研究室研究生竹之内直樹氏及び育種部動物第 1 管理室の五味 浄氏の技術的御支援に対し心から御礼申 し上げる。

\section{References}

Franks F (1987) Nucleation: A maligned and misunderstood concept. Cryo-Lett 8: 53-55.

Kojima T, Oguri N, Shimada K, Souzu H (1988a) Cryomicroscopic observation of ice crystal germination initiated by silver iodide-alginate gel droplets in various aqueous solutions. Cryo-Lett (in press).

Kojima T, Soma T, Oguri N (1986) Effect of silver iodide as an ice inducer on viability of frozenthawed rabbit morulae. Theriogenology 26: 341352.

Kojima T, Soma T, Oguri N (1987a) Application of ice induction method using silver iodide to cryopreservation of bovine embryos. Jpn J Anim Reprod 33: 73-76 (in Japanese).

Kojima T, Soma $T$, Oguri N (1987b) Application of silver iodide as an inducer of ice formation in cryopreservation of mammalian embryos. Cryobiology 24: 547 (abstract).

Kojima T, Soma T, Oguri, N (1988b) Effect of induction of ice nucleation by silver iodide immobilized in freezing of rabbit and bovine embryos. Theriogenology (submitted).

Kojima T, Soma T, Oguri N (1988c) Ice induction 
method by silver iodide for cryopreservation of mammalian embryos. J Freezing Drying (in press) (in Japanese).

Mason BJ (1962) The germination and growth of snow crystals. In: Clouds, Rain \& Rainmaking, the University Press, Cambridge, pp 46-73.

Vonnegut B (1947) The nucleation of ice formation by silver iodide. J Appl Phys 18: 593-595.

\section{要 約}

本研究では，固定化ヨウ化銀による植水方法を用いて緩速冷却後に凍結された胚の移植後の生存を 確かめるために, 牛肧の移植試験を実施した。 $2 \%$ のウ化銀を含むげル状の $2 \%$ アルギン酸ナトリ ウム水溶液を $100 \mathrm{mM}$ の塩化カルシウム水溶液中へ滴下寸ることにより, 固定化ヨウ化銀を作製し た。品質が優ないし良に格付けされた牛の 7 日目胚 5 個を供試し，まず10\%グリセロール・PB1 (10\% FBS を添加）溶液中で 30 分間平衡させた後，胚を 1 個づつ 1 個の固定化ヨウ化銀ドロップレットとと もに $0.25 \mathrm{ml}$ 容量のプラスチックストロー中に吸引した。 $-7{ }^{\circ} \mathrm{C}$ で 5 分間の保持時間を設けた後, $-36^{\circ} \mathrm{C}$ まで $0.3^{\circ} \mathrm{C} / \mathrm{min}$ で冷却を続け, 最終的に液体窒素中へ浸漬して保存した。移植当日に急速に 融解し, 回収した胚を $0.5 \mathrm{M}$ ショ糖・PB1 溶液に浸漬した後, 変性の徵候を見せていた 1 個を除き 残りの 4 個を 2 頭の同期化した受肧牛に各 2 個づつその黄体側子宮角に頸管経由法により移植した。 その結果, どちらの受肧牛も受胎した。起音波診断では, 双胎を確認することはできなかったが, 移 植胚 4 個のらち少なくとも 2 個が胎児に発育したことが認められた。本研究の結果から, 固定化ヨウ 化銀による植氷方法は凍結融解牛胚の移植後の生存性を阻害しないことが推察された。 